\title{
MATERIA AGENS, MATERIA LOQUENS. ECOCRITICISM AND THE NARRATIVE AGENCY OF MATTER
}

\author{
Serenella Iovino \\ University of Turin, Italy
}

\section{Abstract}

Inspired by the theoretical debates about distributed fields of agency and of meaning, the so-called "material turn" sheds its effects also on ecocriticism. Its main conceptual tenet, the agency of matter, has in fact vast implications on the ideas of narrativity and text. If matter is agentic, and endowed with meanings, every material configuration, from bodies to their contexts of living, is "telling," and therefore can be the object of a critical analysis aimed at discovering its stories, its material and discursive interplays, its place in a "choreography of becoming." In this article I will explore this new dimension of ecocriticism looking at the example of some meaningful narratives about the intermingling of living bodies, social forms, and what, following Bruno Latour, we can call "actants": "things" or assemblages of things that, in various forms and patterns, interact and interfere with human life, interlacing with the emerging meanings and agencies. In particular, I will concentrate on visual media and literary "embodied" narratives that show how the "material self" is a crossroads of multiple agencies.

Keywords: Ecocriticism, "Material Turn,” Narrative Agency, "Actant” Bodies.

MATERIA AGENS, MATERIA LOQUENS.

LA ECOCRÍTICA Y LA AGENCIALIDAD NARRATIVA DE LA MATERIA

\section{RESUMEN}

Inspirado por los debates teóricos sobre los campos de distribución de la «agencialidad» y el significado, el denominado «giro material» afecta también al terreno de la Ecocrítica. Su principal axioma, la «agencialidad» de la materia, presenta, de hecho, vastas implicaciones en las ideas sobre la narratividad y el texto. Si la materia es un elemento agente, y provisto de significaciones, entonces toda configuración material, desde los cuerpos a sus entornos vitales, está capacitada para "contar» y por ende puede ser objeto de análisis crítico para descubrir su historia, sus interrelaciones materiales y discursivas, su lugar en la "coreografía de la pertenencia». En este artículo voy a explorar esta nueva dimensión ecocrítica a través de ejemplos de algunas narrativas significativas acerca de la interrelación de los cuerpos vivos, las formas sociales y lo que Bruno Latour llama objetos «actantes», o ensamblajes que, de maneras y formas heterogéneas, interactúan e interfieren con la vida humana, entrelazando con incipientes significados y «agencialidades». En concreto haré hincapié en medios visuales y narrativas con formas aparentemente literarias que muestran cómo el «yo material» es un crisol de múltiples «agencialidades».

Palabras Clave: Ecocrítica, el «giro material», «agencialidad» narrativa, cuerpos «actantes».

DOI: https://doi.org/10.25145/j.recaesin.2018.77.02

Revista Canaria de Estudios Ingleses, 77; november 2018, pp. 11-25; ISSN: e-2530-8335 
It is inescapable, in a volume dedicated to the agency and eloquence of nature, to reflect on the many ways nature can actually "speak," be expressive about the active forces and phenomena that surround and co-determine our existence. This "eloquence," inbuilt in the ancient (and endlessly discussed) idea of a "book of nature," is indeed important for science and for every-day life. Volcanoes, for example, "tell" us about the story of the earth in its making, and of its turbulent past in a time of "more-than-global" warming. Likewise, the Arctic Ice Cap is an indispensable text in which climatologists "read" the story of our atmosphere, and upon which they model future climatic patterns. Again, trees can tell us of years of droughts and rains, of transversally competing deer and rabbits, and of the above - and underground adventures of ecosystems. From its very inception, ecocriticism investigates the way human creativity interacts with nature's narratives. Aldo Leopold's readers will find a poignant example of this in a famous chapter of $A$ Sand County Almanac titled "Good Oak." Here Leopold "reads" the story of eighty years of natural-cultural events in the wood of an oak tree hit by a lightning, after growing in the Wisconsin land from the days of the Civil War to the end of the 1940s:

Fragrant little chips of history spewed from the saw cut, and accumulated on the snow before each kneeling sawyer. We sensed that these two piles of sawdust were something more than wood: they were the integrated transect of a century; that our saw was biting its way, stroke by stroke, decade by decade, into the chronology of a lifetime, written in concentric annual rings of good oak. (33, my emphases; see also 27-39)

Though dismissed as naïve by modern practices of "disenchantment," the metaphor of the "book of nature" is here effective again. ${ }^{1}$

Indeed, every living being tells us evolutionary stories of co-existence, codependence, extinctions and survivals. Fossils do the same, only in a more "static" way. Also we, as human beings, are an example of this storied process, and maybe the easiest one because we are the only ones that, among all things natural, have developed narrative codes which are also linguistic codes: expressive codes, codes through which the world we experience becomes eloquent. With its different waves and currents, ecocriticism has actually enlarged and complicated the spectrum of nature's "voices," which include not only animals or landscapes, but also waste, aliens, and hybrid configurations of beings. However, it has also taught us to be cautious toward -or at least aware of-critical discourses which, more or less openly, anthropomorphize nature. Therefore, when we speak of a natura loquens, we are forced to admit we are using a metaphor. Hence, the central questions of this essay: is there a way to go past metaphors, and to reconcile anthropomorphism with nature's stories? How do we see the stories of nature as they co-emerge with the interpreter's gaze, forming a reciprocity through which reality is constituted?

${ }^{1}$ On this issue, see Wheeler, "Postscript on Biosemiotics" and Markos, Readers of the Book 
Proposing a vision of the world as a dimension where diverse creative forces emerge together and build their "formative histories" (Haraway, The Haraway Reader 2) in ways which are at once natural and cultural, the new materialisms have suggested a pathway: that of considering material agency as a form of expressiveness. And this very expressiveness emerges in the transits and exchanges between corporeal beings and their social and natural environments, shaping "emergent [...] landscapes of interacting biological, climatic, economic, and political forces" (Alaimo, Bodily Natures 2). The purpose here is, as Jane Bennett writes, "to give voice to a vitality intrinsic to materiality," even though this vitality seems to be "both too alien and to close to see clearly and even though linguistic means [might] prove inadequate to the task" (3-4). Besides Bennett's pivotal notion of "vibrant materiality," a significant instance of this attempt to "give voice" to matter is Stacy Alaimo's notion of "trans-corporeality," which pictures the way "bodily natures" express the tangles of organisms and discourses, becoming eloquent about the unsolvable bond connecting life forms and life conditions (see Bodily Natures; "Trans-corporeal Feminism"). From a confluent philosophical angle, another important example is given by David Abram's ecophenomenology, an approach based on what we could define as "sensuous co-emergences" of the languages and signs through which the "more-than-human" world expresses its mind (see The Spell of the Sensuous; Becoming Animal). ${ }^{2}$ In this perspective, an agentic nature is a telling nature. Which is another way of saying that the agency of nature is a narrative agency. This narrative agency is the cypher of material ecocriticism.

\section{NATURAL SIGNS AND THE AGENCY OF MATTER}

Defined briefly and in general terms, material ecocriticism is the study of the way material forms, whether natural and "non-natural" -bodies, things, elements, toxic substances, chemicals, organic and inorganic matter, landscapes, etc.interact with each other and with the human dimension, producing configurations of meanings and discourses that we can interpret as "stories." 3 If referred to living matter, this perspective finds an important correlation with the field of biosemiotics. Intersecting the study of signs with research in biology, zoology, ecology, and the natural sciences in general, biosemiotics is based on the observation that sign processes occur everywhere in nature; they materialize before and alongside with human culture and communicative practices. Since its first conceptualizations in

2 For a panoramic view about the new materialisms, see Coole and Frost, New Materialisms, Dolphijn and van der Tuin, New Materialism, and Alaimo and Hekman, Material Feminisms. On the conceptual genealogy of material ecocriticism see, among other, Iovino, "Material Ecocriticism" and "Steps to a Material Ecocriticism."

3 See, by Iovino and Oppermann, Material Ecocriticism and "Theorizing Material Ecocriticism." 
Charles Sanders Peirce's and Jakob von Uexküll's writings, biosemiotics views organisms as producers of signs, and investigates how signs "emerge" in life forms. Life is here seen as a material phenomenon that is also always a site of semiotic processes: "all living things -from the humblest forms of single-cell life upward-are engaged in sign relations" (Wheeler, "The Biosemiotic Turn" 271). Giving a scientific footing to the metaphor of "the book of nature" (or, if you prefer, showing the solid ground behind the metaphor), biosemiotics "is a semiotic not only of human verbal and non-verbal dimension, but also of the communicative nature of all living organisms as they forge (as they have since the earliest bacterial life) meanings in their environment" (Wheeler, "Postscript on Biosemiotics" 140). In other words, production of signs and production of life are co-dependent: "Meaning is the organising principle of nature" (Maran, "Where Do Your Borders Lie?" 461, emphasis in the original). As it is evident, interpretation plays a crucial part in biosemiotic processes. The DNA "code," for instance, is a text featuring a precise message. This message, however, is not effective until the text is "decoded" by proteins existing in the cells. The "meanings" or instructions of the DNA emerge only when the "code" is "interpreted functionally" (Noble, qtd. in Wheeler, "The Biosemiotic Turn" 275). In the larger perspective of ecosemiotics, as the relationship between organisms and their environment is always mediated by signs, the natural environment becomes itself a text. ${ }^{4}$

Research in biosemiotics thus emphasizes that, co-depending with signs, also "interpretive practices" are indeed an essential part of the "agency" of organisms and living forms. The very survival of organized life depends on these interpretive practices: a carcinogenic cell, for example, "interprets" the message of its DNA in a way which is not "functional" to the survival of the organism of which this cell is a part. Interpretation of semiotic processes, however, is not only crucial to the life of every single organism, but it is also determining for the evolution of the "layers of understanding" that constitute the human and nonhuman participation in the world's becoming. As Wendy Wheeler powerfully articulates it, "Living things are not machines; their reading of the signs which constitutes their world are also always interpretations which are, ipso facto, recursively fed back into that world where further readings and interpretations go on producing new layers or strata of understanding" ("Postscript on Biosemiotics" 154, my emphasis).

The major contribution that biosemiotics can offer to material ecocriticism -and to ecocriticism in general- is that, seeing signs as literally permeating the universe, it expands the discourse of meaning-emergence (or meaning-formation) from the human to the living, from a human-centered cultural level to the level of the "more-than-human," the "natural." Even more important for material ecocriticism is that biosemiotics opens the possibility of participative interpretation processes, as

${ }^{4}$ In ecocritical terms, this might have particular relevance for interpreting nature writing, a genre founded on a sort of semiotic contiguity between a written text and a "living text" (see Maran, "Towards an Integrated Methodology"; see also Wheeler, "Postscript on Biosemiotics"). 
Wheeler's illuminating statement suggests, and as studies about the human involvement in nonhuman sign systems also show. ${ }^{5}$

In general, biosemiotics and material ecocriticism share the idea of the fundamental continuity between natural and cultural forms. Culture, as biosemioticians repeatedly affirm, "emerges" from natural processes -a vision that, in the language of the new materialisms, is synthesized by Haraway's expression "natureculture." But, apart from their methodology, there are essential differences of focus between material ecocriticism and bio- or ecosemiotics. The first of these differences is that the focus of material ecocriticism are not signs, but stories, narratives: articulations of meanings in matter which are developed over time and "plotted" in agentic cooperation by multiple players. The second difference is that, when material ecocriticism talks about matter, it does not exclusively concentrate on the living, or on the "natural."

As previously said, the focus of material ecocriticism are all material forms, whether natural and "non-natural": things, toxic substances, synthetic chemicals, can be enumerated here along with landscapes, bodies, stones, viruses, volcanoes, trees, stars, "stem cells, electricity, food, trash, ... metals" (Bennett x), "tumbleweeds, animal species, the planetary ecosystem, global weather patterns, social movements, health and crime, and economics" (Coole and Frost 13-14). However eccentric these "inventories" might be, they are useful to understand that the natural and the nonnatural, the living and the non-living, things and words, organisms and artifacts, are equally present in our critical horizon. Defining the scope and the outlook of material ecocriticism, these enumerations help us recognize not only that matter is inherently endowed with agency (call it an "immanent" or "a-subjective" life, or a "thing-power": see Bennett 53ss, 2ss), but also that it is a field of "congregational" and differently articulated agencies. Humans share this field with countless nonhuman actors, whose agency -whether intentional or not-forms the fabric of events. The separation between human agency and nonhuman agency is therefore much more blurred than we use to posit it in abstract terms.

The French sociologist and philosopher Bruno Latour uses two important terms to describe this mix of agencies: "actant" and "collectives." More generic than the (human) actor, an actant is "something that acts or to which activity is granted by others" (Latour, "On Actor-Network Theory" 370), an "entity that modifies another entity in a trial," an "intervener" (Latour, Politics of Nature 237, 75). A virus, a chemical substance, electric grids, the market, (nonhuman) actants are the epitome of agentic materiality. The main feature of actants is their cooperative efficacy: "an actant never really acts alone. Its ... agency always depends on the ... interactive interference of many bodies and forces" (Bennett 21). A "collective," therefore, is a coalition of actants into an expanded web of "bodies and forces." It takes place whenever humans are tangled with nonhumans: "there is a social history of things and a 'thingy' history of humans" (Pandora's Hope 18), Latour says. Collectives are

5 On this latter point, see in particular Maran, "Semiotization of Matter." 
everywhere: society, technology, cognitive experiences, industry, financial systems, climate patterns, or science, are all collectives. Indeed, "we live in a hybrid world made up at once of gods, people, stars, electrons, nuclear plants, and markets" (16). Far from erasing any formal difference, this vision infers a co-operative juxtaposition, an exchange of properties between human and nonhuman beings.

The ontology that a perspective based on networks of agencies implies is that things and nonhumans in general are no longer to be seen as mere objects, statically depending on a subject, but as "full-fledged actors" (Latour, Pandora's Hope 174). Agency is thus a fold in which humans and nonhumans are materially tied together. Other thinkers, including Donna Haraway and Rosi Braidotti, have developed these considerations in a line of thought called "posthumanism." Far from banally reducing humans to cyborgs, posthumanism is a complex vision of the human based on the structural hybridity of the human itself, whose agency and being depend from the agency and being of the nonhuman. Our health, for example, depends on the health of our bacteria. Not only that: in every earthly event, the human is never completely alone, being instead always hybridized with the nonhuman: "Consider things, and you will have humans. Consider humans, and you are by that very act interested in things. Bring your attention to bear on hard things, and see them become gentle, soft or human. Turn your attention to humans, and see them become electric circuits, automatic gears or softwares," writes Latour again ("The Berlin Key" 20). Between humans and nonhumans, the boundaries are more like connective tissues than iron walls.

\section{NETWORKS OF AGENCIES AND MATERIAL NARRATIVES}

As these reflections imply, human agency is not secluded from the agency of the nonhuman world. It is clear that to talk of human agency alone is an abstraction, because actions, and therefore stories, formative patterns -whether social, natural, or technological- are always "co-active choreographies" in which humans dance (or collide) with nonhuman forces, phenomena, and things that share with them the stage of space and time. As Jane Bennett says, "Each human is a heterogeneous compound of wonderfully vibrant, dangerously vibrant, matter" (12-13), and therefore it is not difficult to conclude that, "in a knotted world of vibrant matter, to harm one section of the web might well be to harm oneself" (13). This clearly means that we do not simply have agency, but more exactly we are in and contribute to networks of agencies. For material ecocriticism these networks of agencies manifest themselves in forms which can be read as narratives. This practice of "reading" is

${ }^{6}$ On posthumanism, see Braidotti, The Posthuman; Haraway, When Species Meet; Hayles, How We Became Posthuman; Marchesini, Post-human; Wolfe, What is Posthumanism? On material ecocriticism and posthumanism, see Iovino, "Material Ecocriticism." 
our participation in the world's "differential becoming" and is in itself responsible for crafting further levels of reality; it is, as Wheeler says, "fed back into [the] world ... producing new layers or strata of understanding" ("Postscript on Biosemiotics" 154). The "narrative agency" of matter is implied in the idea of the world's textuality, but it is also implied in the idea that this textuality is a reciprocity through which human and nonhuman agents are "actively constitutive" of the world. In this sense, a literary representation, as well as a critical interpretation, are not barely a product of human creativity, but rather a combination of human and nonhuman agencies assuming a narrative form. In this narrative, the world itself-along with all of its collectives-is a player.

A good case in point to clarify this idea via a material-ecocritical analysis is The Majestic Plastic Bag, a short "mockumentary" created by director Jeremy Konner on behalf of the California organization "Heal the Bay" (www.healthebay.org) in 2010. ${ }^{7}$ Praised in many film festivals by audience and critics, the documentary denounces the gravity of plastic pollution in the oceans by ironically taking a plastic bag as a protagonist. Narrated by Jeremy Irons, this mock-ecological "drama" ends with the bag reaching its final destination: the Great Pacific Plastic Patch. Mimicking the style of wildlife documentaries, this "plastic migration" is represented as a natural process, and the bag displays the same inborn determination of a brooding penguin in the Antarctic winter, or of a salmon swimming upstream to mate and die in a Norwegian river. Portrayed as a mixture of survival instinct (it "flees for its life") and dawning intentionality (it "uses" the wind to move), the bag is clearly shown to possess a form of agency, which characterizes both its "social" and "natural" behavior as a member of the "petroleum species." Conforming to the "natural" role of its "species," the plastic bag "serves" society in the same way -the narrator seems to imply- bees "serve" agriculture by pollinating flowers. Once it has accomplished its "social function," the bag is ready to complete its "plastic cycle of life." But first it has to struggle against "co-evolutionary" competitors, such as the "Teacup Yorkie" (a miniature Yorkshire terrier), or marine animals that "feed from plastic." A denizen of urban ecosystems, the plastic bag has a "trajectory" of life, something we can imagine as inscribed in its "DNA," which leads it to end its adventure in its locus naturalis: the Great Pacific Plastic Patch, an area of human waste -mostly plastic- within the North Pacific Gyre, estimated to be twice the size of Texas.

Providing an ironical representation of a tragic ecological reality, the documentary sheds light on the illusion behind the "plastic cycle of life"-an illusion which corresponds to the one underlying the two "dangers of not owning a farm" mentioned by Aldo Leopold in the first pages of $A$ Sand County Almanac: "One is the danger of supposing that breakfast comes from the grocery, and the other that the heat comes from the furnace" (6). Just like breakfast does not come by nature from

The documentary is available on youtube at: http://www.youtube.com/watch?v=GLgh9h2 ePYw\&feature=plcp. I am grateful to Christopher Schliephake for bringing this film to my attention. 
the grocery, and the heat does not come by nature from the furnace, plastic bags do not come from or tend toward whatever "natural" place, being rather a product of society and technology as collectives of human and nonhuman agencies. The Great Pacific Patch itself is not so much of a "natural" thing: almost as big as a continent, it is indeed one of the most alarming phenomena of global environmental pollution. Therefore, what Jeremy Irons's voice does not say, but strongly implies -in other words the "subtext" of the mockumentary- is: what is the real story of the plastic bag? Shall we consider it "normal" and "natural" that it concludes its "plastic cycle of life" in the ocean, after having been manufactured in industrial plants, using chemical and synthetic substances that are clearly alien to the metabolism of marine life and of living organisms in general? Not many people would say that the "natural" final destination of the plastic bag, whether a character in a mockumentary or a thing in the "real world," is the Pacific Ocean. Plastic does not belong to sea environments, it is not, as the final lines of the film denounce, "indigenous" to that ecosystem. Still, this is what happens; this is what happens now, in this very moment, all over the planet. The hoarding of huge amounts of plastic objects in the oceans is, to quote Latour again, a real Thing, important not as a "matter of fact," but rather as a "matter of concern" ("Why Has Critique Ran out of Steam" 157).

As the example shows, what Steve Mentz calls "our marine alterity" is not simply related to the "combination of hostility and fertility" which "captures the sea's role" in literary metaphors as well as in our material existence as potential castaways ("Toward a Blue Cultural Studies" 1002-1003, my emphasis). Here this hostile alterity is literally inbuilt in the uncontrollable presences, transits, and unsolvable "states of suspension" which define the realm of a "marine trans-corporeality," as Stacy Alaimo has argued ("States of Suspension"). The hostility of this newly induced marine presences affects not only us humans, but the sea itself as a whole -a "whole" which covers the largest part of this planet. ${ }^{8}$

Along with the many films exposing plastic pollution in the oceans, The Majestic Plastic Bag is a useful device to clarify both the concept of matter and the concept of agency as they are used in the context of material ecocriticism: the concept of matter as a "storied matter" and the concept of agency as a "narrative agency." In so doing, it helps us prevent potential misunderstandings about the concept of agency itself. Agency is a thorny notion. If we ask, "do plastic bags have agency?", the answer to this question will be both "yes" and "no." If by agency we mean something close to intentionality, or a "genetic code" inscribed in inorganic matter, then, the answer will be "no": plastic bags do not have agency. They do not have DNA or instincts; they do not march like penguins or swim upstream to fulfill their story of love and death like salmons do. They are not alive in a biological sense: they are things, and therefore their only "power" is a "thing-power," as Jane Bennett explains in Vibrant Matter. But if we posit this question in other terms, and ask how does plastic, in its materiality, interact with other materialities,

\footnotetext{
8 On this topic, see also Alaimo, "Oceanic Origins, Plastic Activism."
} 
other bodies, energy cycles, ecosystems, human life, health, economy, and politics, maybe we will admit that there is an agentic dimension in the material existence of this bag. Material ecocriticism tries to elicit the facets of this agentic dimension by asking: what lies beneath and beyond a thing's agency? Which dynamics, resources, syntheses, discourses, meanings, properties, practices? What combinations of material and discursive elements are entangled with it? What are the stories told by this plastic bag in its narrative agentic capacity?

From its accidental "birth" in 1899, when the German scientist Hans von Pechmann noticed a waxy residue at the bottom of a test tube, to its widespread industrial use, polyethylene has gone a long way. It has actually inaugurated a new and eerie kind of eternity, as Primo Levi remarked. In his Periodic Table (1975) Levi noted that polyethylene is "flexible, light, and splendidly impermeable: but it is also a bit too incorruptible, and not by chance God Almighty himself, although he is a master of polymerization, abstained from patenting it: He does not like incorruptible things" (141). According to the Worldwatch Institute's State of the World 2004 report, some 4-5 trillion plastic bags were produced on a global scale in 2002 (22). Every year Americans dispose of over 100 billion polyethylene bags, of which only $0.6 \%$ are actually recycled. ${ }^{9}$ After having been a visible (and quasi-omnipresent) part of our "collective," most of the plastic produced in the world will eventually be washed out to sea and reach the Great Pacific Plastic Patch and the other continents of plastic suspended in our oceans. Except for satellites and marine creatures that mistake it for plankton, it will not be there to be seen; however, it will continue to be an actant in the collective of our global ecology: the "plastic cycle of life" practically interferes with any other cycle of life, present and future, epitomizing and determining a "bio-convergence between organic and inorganic, the natural and the artificial" (Bodei 80, my translation). But, unlike living entities, plastic is virtually indestructible.

This incorruptibility, however, is the key of the "survival" of all the plastic we use. We might forget our bag, but it will outlast our memory and our very presence in this world. Maybe it will be part of the fish someone will eat, and come back, in minute particles, to the life of our collective. It will mingle with the life of other organisms, whether human or not, and cause pollution, illness, death. It will have (and it has already) a story -a story, which is embodied in a grid of interacting subjects. A material story. Talking of storied matter and of narrative agencies means to analyze the things around us and in us as parts of a thick fabric of stories. It means to recognize patterns of significances in the agency of things, in bodies, in material phenomena. It means to see the network of agencies that constitutes material phenomena, and to understand our story as co-originated

9 These and more data are available on line on the World Watch Institute's website. See http://www.worldwatch.org/system/files/Plastic\%20Bags.pdf and http://www.worldwatch.org/ node/5565. On plastic and plankton, it is worth noticing that, already in 2001, the proportion of plankton units to plastic debris particles was estimated of 1 against 6. See Moore et al., "A Comparison of Plastic and Plankton in the North Pacific Central Gyre." 
with the agentic stories of matter. The plastic bag, however you might consider its agency, emerges as a knot in a web of stories. And these stories, whether perceived or interpreted by the human mind or not, actually shape trajectories that do exist and have a formative, enactive power. Just like the past of the earth -the transformative stories built by telluric powers, magnetic forces, clashing and melting elements, and dawning forms of life- has its agentic capacity extended in our present, the matter that we don't see, perceive, or suspect, interacts with other matter, including the human.

The story of the plastic bag exemplifies "the extent to which human being and thinghood overlap, the extent to which the us and the it slip-side into each other" (Bennett, 4). This more-than-human interplay discloses a narrative dimension, which is essential in the structure of ecological discourse. Material ecocriticism wants to shed light on it. Reading into the "thick of things" material ecocriticism aims to explore not only the agentic properties of material forms, whether living or not, whether organic, "natural" or not, but also how these properties act in combination with other material forms and their properties, and with discourses, with evolutionary paths, with political decisions, with pollution, with other stories.

This does not mean that material ecocriticism is not concerned with human narrative agency, for example literature. Quite the opposite: when human creativity "plays" together with the narrative agency of matter, it can generate stories and discourses that mirror the complexity of our collective, shedding light on its multiple and "fractal" causal connections, thus enlarging our horizon of meanings. Narrative agency and human creativity integrate each other producing new and more complex levels of reality. Like in every complex system, here the whole is always bigger than the sum of the parts. These human and nonhuman "parts" produce narrative "emergences" that amplify reality, also affecting our cognitive response to this reality. In ethical and political terms, this has a great potential for a practice of social liberation. Knowing, and seeing the connections of the acting elements, is in fact an indispensible act of cognitive democracy, and has therefore socially liberating effects.

Naples' waste crisis and its narratives are a good example of it. We have here a line of narrative agents, made of trash, pollution, hazardous substances, landscape, illness, and toxic bodies. Already alone, these actants tell us a story of political discourse intermingled with territorial exploitation, environmental contamination, illegal activities ("ecomafia"), and thwarted citizenship. Here one of Italy's higher cancer rates speaks its material language of political failure and socio-ecological decline. And here writers and film directors undergo bodily exposures to physical dangers and environmental contaminations while creating their works, thereby revealing on several levels just how distributed, multiple, and posthuman narrative agency can be. I think of Saviano's Gomorrah (2006) a book written by its author while exposed to criminal threats and toxic pollution; and of Ivana Corsale's documentary film Campania In-felix/Unhappy Country (2011). In Corsale's work, the situation of the so-called "Triangle of Death" (a former agricultural area near Naples now completely poisoned by several hazardous substances, including dioxin and polychlorinated biphenyls) is narrated through the bodies and stories of people, 
animals, and the land. Toxic bodies and toxic stories. Material narrative agency combines with human narrative agency in a discourse that penetrates a complex more-than-human reality. ${ }^{10}$

An even more eloquent case comes from the narrative agents at work in Italy's first big ecological disaster, which happened in Seveso, near Milan, in 1976. A cloud of dioxin burst out from an industrial site, poisoning people, animals, and land, causing miscarriages and fetal malformations. In a catholic and conservative reality, the most affected subjects (besides nonhuman beings) were women, their bodies, and their right to self-determination. This is clearly shown by a novel written by Laura Conti, one of the leading figures of environmental activism in Italy. Reading her narration and relating it to the materiality of the accident in its many levels, it becomes clear that the story is not conveyed by humans only, but also by dioxin. Dioxin interferes and co-acts with the bodies of living organisms and living land. Dioxin is a narrative agent: poisoning bodies and territory, it reveals at the same time the discriminatory practices, social constructs, and ideological discourses that "infiltrate" Seveso's society, notably the women's bodies. ${ }^{11}$

From these examples of "embodied narratives," it should be made clear what material ecocriticism means for "narrative agency." The human self, too, is a complex crossroads of agencies, and of stories. It is therefore legitimate to ask: who is the storyteller of these stories narrated through and across bodies by agents, such as toxic waste, sick cells, individual organisms, and social forces? Who is really the "narrating subject," if things are narrative agencies? Rather than (metaphorically!) "killing" the author, we should maybe re-draw the boundaries of authorship in a more realistic way. Narrative agents like dioxin, polychlorinated biphenyl, or the polyethylene of the plastic bag have a great revealing power. Literature, film, and art are ways to enhance this power and enact the eloquence of the world.

This is something that Italo Calvino, like Levi a writer with a scientific aptitude, had perfectly understood. Many examples could be quoted from his work, but I limit myself to the final lines of his Six memos for the Next Millennium:

Think what it would be to have a work conceived from outside the self, a work that would let us escape the limited perspective of the individual ego, not only to enter into selves like our own, but to give speech to that which has no language, to the bird perching on the edge of the gutter, to the tree in spring and the tree in the fall, to stone, to cement, to plastic... Was this not perhaps what Ovid was aiming at, when he wrote about the continuity of forms? And what Lucretius was aiming at when he identified himself with that nature common to each and every thing? (124)

${ }^{10}$ I have illustrated these examples in "Stories from the Thick of Things." On Saviano's Gomorrah, see also my "Naples 2008, or, The Waste Land."

${ }^{11}$ For a material-feminist interpretation of Seveso's accident and of Conti's narratives, see my essay "Toxic Epiphanies." 
The continuity of all the existing forms is a narrative continuity, for material ecocriticism. It is a story written and enacted by a collective of agencies that intersect and interact with the self.

At the end of this discourse, maybe the word "story" will continue to be a metaphor, and to sound anthropomorphic. Let us concede it: we do not know whether nonhuman agency -taken in itself-tells a story. But we know that, if we want to read into the "thick of things," we have to see this agency as if it was telling us a story. And we can try to listen to this story coming "from outside the self," knowing that the human is not its emanating center. We cannot help being humans, of course; but we can certainly learn to see the human in different terms. In a world populated by narrative agents, by "gods, people, stars, electrons, nuclear plants, and markets," material ecocriticism can give us some useful directions.

Reviews sent to author: 21 March 2018

Revised paper accepted for publication: 26 June 2018 


\section{WORKS CITED}

Aвram, David: Becoming Animal: An Earthly Cosmology. New York: Pantheon, 2010.

Aвram, David: The Spell of the Sensuous: Perception and Language in a More-Than-Human World. New York: Pantheon, 1996.

Alaimo, Stacy: Bodily Natures: Science, Environment, and the Material Self. Bloomington: Indiana University Press, 2010.

Alaimo, Stacy: "Oceanic Origins, Plastic Activism, and New Materialism at Sea." Material Ecocriticism. Eds. Serenella Iovino and Serpil Oppermann. Bloomington: Indiana UP, 2014. 186-203.

Alaimo, Stacy: "States of Suspension: Trans-Corporeality at Sea." ISLE 19.3 (Summer 2012): 476-493.

Alaimo, Stacy: “Trans-corporeal Feminisms and the Ethical Space of Nature." Material Feminisms. Eds. Stacy Alaimo and Susan Hekman. Bloomington: Indiana University Press, 2008. 237-64.

Alaimo, Stacy and Hekman, Susan (Eds.): Material Feminisms. Eds. Stacy Alaimo and Susan Hekman. Bloomington: Indiana University Press, 2008.

Bennett, Jane: Vibrant Matter: A Political Ecology of Things. Durham: Duke University Press, 2010.

Braidotti, Rosi: The Posthuman. London: Polity Press, 2013.

Boder, Remo: La vita delle cose. Rome-Bari: Laterza, 2009.

Calvino, Italo: Six Memos for the Next Millennium (1988). Trans. Patrick Creagh. London and New York: Penguin Books, 2009.

Coole, Diana and Frost, Samatha: "Introducing the New Materialisms." New Materialisms: Ontology, Agency, and Politics. Eds. Diana Coole and Samantha Frost. Durham: Duke University Press, 2010. 1-43.

Coole, Diana and Frost, Samatha (Eds.): New Materialisms: Ontology, Agency, and Politics. Eds. Diana Coole and Samantha Frost. Durham: Duke University Press, 2010. 1-43.

DolphiJn, Rick and VAN DER TuIn, Iris (Eds.): New Materialism: Interviews and Cartographies. Ann Arbor, Mich.: Open Humanities Press, 2012.

De Landa, Manuel: A Thousand Years of Nonlinear History. New York: Zone, 1997.

Haraway, Donna J.: The Haraway Reader. New York: Routledge, 2004.

Haraway, Donna J.: When Species Meet. Minneapolis: University of Minnesota Press, 2008.

Hayles, Katherine N.: How We Became Posthuman: Virtual Bodies in Cybernetics, Literature, and Informatics. Chicago: The University of Chicago Press, 1999.

Iovino, Serenella: "Material Ecocriticism: Matter, Text, and Posthuman Ethics." Literature, Ecology, Ethics: Recent Trends in European Ecocriticism. Eds. Timo Müller and Michael Sauter. Heidelberg: Winter Verlag, 2012. 51-68.

Iovino, Serenella: "Naples 2008, Or, The Waste Land: Trash, Citizenship, and an Ethic of Narration." Neohelicon 36.2 (2009): 335-46.

Iovino, Serenella: "Steps to a Material Ecocriticism. The Recent Literature About the 'New Materialisms' and Its Implications for Ecocritical Theory.” Ecozon@ 3.1 (2012): 134-45. Web. 10 December 2012. 
Iovino, Serenella: “Toxic Epiphanies: Dioxin, Power, and Gendered Bodies in Laura Conti’s Narratives on Seveso." International Perspectives in Feminist Ecocriticism. Eds. Greta Gaard, Simon C. Estok, and Serpil Oppermann. New York: Routledge, 2013. 37-55.

Iovino, Serenella and Oppermann, Serpil (Eds.): Material Ecocriticism. Bloomington: Indiana University Press, 2014.

Iovino, Serenella and Oppermann, Serpil: "Material Ecocriticism: Materiality, Agency, and Models of Narrativity.”Ecozon@. 3.1 (2012): 75-91. Web. 10 December 2012.

Iovino, Serenella and Oppermann, Serpil: “Theorizing Material Ecocriticism: A Diptych.” ISLE 19.3 (Summer 2012): 448-475.

Latour, Bruno: "On Actor-Network Theory: A Few Clarifications Plus More than a Few Complications.”Soziale Welt 47 (1996): 369-82. Print.

Latour, Bruno: Pandora's Hope: Essays on the Reality of Science Studies. Cambridge, MA: Harvard UP, 1999. Print.

Latour, Bruno: Politics of Nature: How to Bring the Sciences into Democracy. Trans. Catherine Porter. Cambridge: Harvard University Press, 2004.

Latour, Bruno: “The Berlin Key, or How to Do Things with Words.” Matter, Materiality and Modern Culture. Ed. Paul M. Graves-Brown. London: Routledge, 2000. 10-21.

Latour, Bruno: "Why Has Critique Ran out of Steam: From Matter of Fact to Matter of Concern." Things. Ed. Bill Brown. Chicago and London: The University of Chicago Press, 2004. 151-173.

Leopold, Aldo: A Sand County Almanac: With Essays on Conservation (1949). New York: Oxford University Press, 2001.

Levi, Primo: The Periodic Table (1975). Trans. Raymond Rosenthal. New York: Schocken Books, 1984.

Maran, Timo: "An Ecosemiotic Approach to Nature Writing." PAN: Philosophy Activism Nature 7 (2010): 79-87.

Maran, Timo: "Semiotization of Matter: A Hybrid Zone between Biosemiotics and Material Ecocriticism." Material Ecocriticism. Eds. Serenella Iovino and Serpil Oppermann. Bloomington: Indiana UP, 2014. 141-154.

Maran, Timo: "Towards an Integrated Methodology of Ecosemiotics: The Concept of Nature-Text." Sign Systems Studies 35.1/2 (2007): 269-294.

Maran, Timo: "Where Do Your Borders Lie? Reflections on the Semiotical Ethics of Nature." Nature in Literary and Cultural Studies: Transatlantic Conversations on Ecocriticism. Ed. Catrin Gersdorf and Sylvia Mayer. Amsterdam: Rodopi, 2006. 455-76.

Marchesini, Roberto: Post-human: Verso nuovi modelli di esistenza. Torino: Bollati Boringhieri, 2002.

Markos, Anton: Readers of the Book of Life: Contextualizing Developmental Biology. Oxford: Oxford University Press, 2002.

Mentz, Steve: “Toward a Blue Cultural Studies: The Sea, Maritime Culture, and Early Modern English Literature." Literature Compass 6/5 (2009): 997-1013.

Moore, C.J., Moore, S.L., Leecaster, M.K. and Weisberg, S.B.: "A Comparison of Plastic and Plankton in the North Pacific Central Gyre." Marine Pollution Bulletin 42 (December 2001): 1297-1300. 
Oppermann, Serpil: "From Ecological Postmodernism to Material Ecocriticism: Creative Materiality and Narrative Agency." Material Ecocriticism. Eds. Serenella Iovino and Serpil Oppermann. Bloomington: Indiana UP, 2014. 21-36.

The Majestic Plastic Bag. Screenplay by Sarah May Bates and Regie Miller. Dir. Jeremy Konner. Prod. Heal the Bay. 2011.

Wheeler, Wendy: “Postscript on Biosemiotics: Reading Beyond Words-and Ecocriticism.” Earthographies: Ecocriticism and Culture. Special Issue of New Formations 64 (2008): 137-154.

Wheeler, Wendy: "The Biosemiotic Turn: Abduction, or the Nature of Creative Reason in Nature and Culture." Ecocritical Theory: New European Approaches. Eds. Axel Goodbody and Kate Rigby. Charlottesville: University of Virginia Press, 2011. 270-282.

Wheeler, Wendy: The Whole Creature: Complexity, Biosemiotics and the Evolution of Culture. London: Lawrence \& Wishart, 2006.

Wolfe, Cary: What is Posthumanism? Minneapolis: University of Minnesota Press, 2009.

Worldwatch Institute: State of the World 2004. Special Focus: The Consumer Society. New York: W.W. Norton, 2004. 
